\title{
Transcriptomic analysis of genetically defined autism candidate genes reveals common mechanisms of action
}

\author{
Thomas A Lanz ${ }^{1}$, Edward Guilmette ${ }^{1}$, Mark M Gosink², James E Fischer ${ }^{3}$, Lawrence W Fitzgerald ${ }^{1,5}$, \\ Diane T Stephenson ${ }^{1,6}$ and Mathew T Pletcher ${ }^{4^{*}}$
}

\begin{abstract}
Background: Austism spectrum disorder (ASD) is a heterogeneous behavioral disorder or condition characterized by severe impairment of social engagement and the presence of repetitive activities. The molecular etiology of ASD is still largely unknown despite a strong genetic component. Part of the difficulty in turning genetics into disease mechanisms and potentially new therapeutics is the sheer number and diversity of the genes that have been associated with ASD and ASD symptoms. The goal of this work is to use shRNA-generated models of genetic defects proposed as causative for ASD to identify the common pathways that might explain how they produce a core clinical disability.

Methods: Transcript levels of Mecp2, Mef2a, Mef2d, Fmr1, Nlgn1, Nlgn3, Pten, and Shank3 were knocked-down in mouse primary neuron cultures using shRNA constructs. Whole genome expression analysis was conducted for each of the knockdown cultures as well as a mock-transduced culture and a culture exposed to a lentivirus expressing an anti-luciferase shRNA. Gene set enrichment and a causal reasoning engine was employed to identify pathway level perturbations generated by the transcript knockdown.

Results: Quantification of the shRNA targets confirmed the successful knockdown at the transcript and protein levels of at least 75\% for each of the genes. After subtracting out potential artifacts caused by viral infection, gene set enrichment and causal reasoning engine analysis showed that a significant number of gene expression changes mapped to pathways associated with neurogenesis, long-term potentiation, and synaptic activity.

Conclusions: This work demonstrates that despite the complex genetic nature of ASD, there are common molecular mechanisms that connect many of the best established autism candidate genes. By identifying the key regulatory checkpoints in the interlinking transcriptional networks underlying autism, we are better able to discover the ideal points of intervention that provide the broadest efficacy across the diverse population of autism patients.
\end{abstract}

\section{Background}

Autism spectrum disorder (ASD) is a heterogeneous developmental disease that is primarily characterized by behavioral and social impairments such as the presence of repetitive or ritualistic activities, social withdrawal, and difficulty with proper communication. ASD is more commonly diagnosed in male individuals at a 4:1 ratio and its incidence has notably risen over time. It is currently estimated that ASD afflicts up to one out of

\footnotetext{
* Correspondence: Mathew.Pletcher@pfizer.com

${ }^{4}$ Rare Disease Research Unit, Pfizer, Inc, Cambridge Park Drive, Cambridge, MA 02140, USA

Full list of author information is available at the end of the article
}

every eighty-eight individuals and is now counted as the second most common developmental disability after intellectual disability [1-3]. Current treatment options for autism are limited, focusing primarily on behavioral therapies and repurposed drugs whose primary indication is not autism.

It is long been appreciated that ASD has a strong genetic component underlying its etiology. Early twin studies, examining the co-inheritance of ASD among monozygotic twins, reported a heritability rate for ASD between $60 \%$ and $90 \%$ [4]. The role of genetics in ASD has been further elucidated and refined at the single gene level as tools such as genome-wide association

\section{Biomed Central}


studies (GWAS), copy number variant (CNV) mapping, and whole exome/genome sequencing have been applied to the disease [5-10]. A clear association has been demonstrated between genetic variants in genes, such as Contactin-associated protein-like 2 (Cntnap2) and Semaphorin-5A (Sema5A), and ASD, and the localization of rare deletions and duplications has not only led to the identification of new autism candidate genes, such as SH3 and multiple ankyrin repeat domains 3 (Shank3), but also the creation of new mouse models that parallel ASD at both the genetic and behavioral level [11-14].

Our understanding of the genetics and molecular mechanisms of ASD has also been greatly enriched by the study of rare diseases caused by mutations in a well-defined single gene with symptomatic overlap with ASD. Two of the best known examples of this are Fragile $\mathrm{X}$ and Rett syndromes. Fragile $\mathrm{X}$ is caused by an expansion of a CGG repeat in the Fragile $\mathrm{X}$ mental retardation-1 (Fmr1) gene and results in mental retardation. Fragile X, because it is X-linked, is preferentially found in male individuals and $25 \%$ to $33 \%$ of Fragile $\mathrm{X}$ patients also meet the criteria for ASD, making it one of the most common genetic causes of autism [15]. Rett Syndrome is also X-linked but unlike Fragile $\mathrm{X}$ and ASD, it is predominantly diagnosed in female individuals, because the hemizygous state is often lethal. Rett syndrome too is marked by mental retardation and frequent comorbidity with autism. In addition to being directly tied to ASD through Rett, Methyl-CpG binding protein 2 (Mecp2), a transcription factor mutated in Rett, regulates the expression of other genes that have been tied to ASD, including Brain-derived neurotrophic factor (Bdnf) [16,17].

Through the use of modern genetic methods and the study of syndromic forms of autism, over 200 genes have been associated with ASD [18]. In an attempt to gain a better understanding of molecular pathophysiology of the disease, tools such as pathway analysis [19] and protein-protein interaction networks [20-22] have been deployed to identify common mechanisms among these autism-risk genes, and one of the dominant themes that has emerged is a convergence on synapse integrity and dendritic spine formation [23-25]. Phosphatase and tensin homolog (Pten), the causative gene for Cowden syndrome - another syndromic form of autism - is shown to cause increased neuronal spine density, dysfunction in excitatory and inhibitory synaptic activity and decreased synaptic plasticity when deleted [26-28]. Shank3 encodes a synaptic scaffolding protein while Neuroligin 1 and 3 (Nlgn1, Nlgn3) produce synaptic cellular adhesion molecules. All three genes have been shown to be altered in ASD patients [29-31]. Finally, Myocyte enhancer factor $2 A$ and $2 D(M e f 2 A, M e f 2 D)$ are activity-dependent genes that encode transcription factors regulating multiple additional genes implicated in ASD (Ube3A, Slc9A6, Pcdh10, and C3orf58) [32], and knockdown of these genes in primary neurons has been shown to regulate synapse density [33].

Despite the clues that have been provided by these genetic links, a true understanding of how those genetic defects translate into altered biology have continued to be elusive and therefore have made the development of new therapies for ASD difficult. The current gross appreciation of impacted dendritic spines and synaptic health falls short of the digital visualization of the molecular mechanisms of ASD necessary to advance the field. Therefore, in this study, we sought to determine the molecular consequences of the loss of function of these diverse genes that have been genetically implicated in autism by use of an in vitro model system. Primary neuronal cultures are a well-established model for studying fundamental synaptic biology with a well-characterized trajectory of synaptic differentiation and function [5,34]. These cultures have proven to be a robust system for characterizing the transcriptional consequences of synaptic modulation under a number of settings $[32,35,36]$. We have focused on cortex as a tissue of origin based on observation of pathologic changes in post-mortem ASD cortex [8] and prior work studying ASD-relevant gene function in cortical neurons [10].

By knocking down Mecp2, Mef2a, Mef2d, Fmr1, Nlgn1, Nlgn3, Pten, and Shank3 (Table 1) in murine primary cortical neurons, we were able to compare and contrast the varying transcriptional profiles of each transcriptional inhibition to arrive at core signaling pathways that unite this otherwise disparate group. Pathways that are in common between the various candidate genes would provide one potential explanation of how a mutation in each them might produce the same clinical outcome - ASD. As all of these genes play a role relevant for synaptic structure or function, the hypothesis was that common downstream genes and pathways might be perturbed. For a disorder with heterogeneous genetic backgrounds that produce common behavioral phenotypes, a common molecular pathway could provide a new avenue for therapeutic intervention.

\section{Methods}

\section{Lentiviral shRNA construct generation and production}

Lentiviral constructs were generated by cloning annealed and kinased, complementary oligonucleotides into the lentiviral vector pLL3.7_H1 (a version of pLL3.7, Patrick Stern-MIT, modified to encode human $\mathrm{H} 1$ promoter to drive short-hairpin (sh)RNA expression). Individual gene's target sense sequence (Table 2) followed by the loop sequence TTCAAGAGA, targets' corresponding antisense and TTTTTT terminator sequences oligos were ligated (New England Biolabs, Ipswich, MA, USA) into 
Table 1 Description of genes selected for short-hairpin (sh)RNA knockdown and linkage to ASD

\begin{tabular}{|c|c|c|c|c|}
\hline Gene & Function & $\begin{array}{l}\text { Cellular } \\
\text { localization }\end{array}$ & Genetic evidence & Reference \\
\hline Methyl CpG binding protein 2 (Mecp2) & Transcriptional repressor & Nuclear & $\begin{array}{l}\text { Causes Rett syndrome, which shares some } \\
\text { symptom domains with autism }\end{array}$ & {$[37]$} \\
\hline $\begin{array}{l}\text { Myocyte-specific enhancer factor } \\
2 a(\text { Mef2a) }\end{array}$ & Transcription factor & Nuclear & $\begin{array}{l}\text { Rare single gene mutation in downstream targets } \\
\text { associated with Autism symptom domains }\end{array}$ & {$[32]$} \\
\hline $\begin{array}{l}\text { Myocyte-specific enhancer factor } \\
2 d \text { (Mef2d) }\end{array}$ & Transcription factor & Nuclear & $\begin{array}{l}\text { Rare single gene mutation in downstream targets } \\
\text { associated with Autism symptom domains }\end{array}$ & {$[32]$} \\
\hline Fragile $X$ mental retardation 1 (Fmr1) & RNA binding protein & Nuclear & $\begin{array}{l}\text { Causes Fragile } X \text {, which shares some symptom } \\
\text { domains with autism }\end{array}$ & {$[38]$} \\
\hline Neuroligin-1 (N/gn1) & Synaptic remodeling & Synaptic & $\begin{array}{l}\text { Rare single gene mutation associated with } \\
\text { autism symptom domains }\end{array}$ & {$[30]$} \\
\hline Neuroligin-3 (NIgn3) & Synaptic remodeling & Synaptic & $\begin{array}{l}\text { Rare single gene mutation associated with } \\
\text { autism symptom domains }\end{array}$ & {$[31]$} \\
\hline Phosphatase and tensin homolog (Pten) & $\begin{array}{l}\text { Regulator of the } \\
\text { cell cycle }\end{array}$ & Nuclear and synaptic & $\begin{array}{l}\text { Causes Cowden syndrome which shares some } \\
\text { symptom domains with autism }\end{array}$ & {$[26,39]$} \\
\hline $\begin{array}{l}\text { SH3 and multiple ankyrin repeat } \\
\text { domains } 3 \text { (Shank3) }\end{array}$ & Scaffold protein & Synaptic & $\begin{array}{l}\text { Rare single gene mutation associated with } \\
\text { autism symptom domains }\end{array}$ & {$[12,29]$} \\
\hline
\end{tabular}

the BamHI (5') and XhoI (3') cloning sites downstream of the human $\mathrm{H} 1$ promoter into pLL3.7_H1.

Lentivirus was produced per manufacturer's instructions via quadruple co-transfection of shRNA-containing pLL3.7_H1 plasmid along with the 3 plasmid ViraPower (Life Technologies, Grand Island, NY, USA) system into HEK293T cells. Then, 24 hours post transfection, the media were changed to complete neurobasal media (Life Technologies) and lentivirus-conditioned media were harvested 48 hours later. Functional titer was determined based on green fluorescent protein (GFP) co-expression in HEK293T cells using flow cytometry (FACscalibur, Becton Dickenson, Franklin Lakes, NJ, USA). Optimal lentiviral transduction of primary cultured cortical neurons was determined to be a multiplicity of infection (MOI) of 3.0, based on fluorescence.

Primary neuronal cultures and transductions

Mouse primary neuronal cultures were prepared from day-16 C57BL6/J embryos. All procedures related to animal care and treatment were conducted under a protocol approved by the Pfizer Institutional Animal Care and Use Committee, according to the guidelines of the National Research Council Institute for Laboratory Animal Research Guide for the Care and Use of Laboratory Animals and the US Department of Agriculture Animal Welfare Act and Animal Welfare Regulations. Briefly, timed pregnant dams were received from Jackson Laboratories and whole brains were removed and plated into Hank's (Life Technologies) solution for dissection (10uM of $\mathrm{MgCl}_{2} ; 7 \mathrm{uM}$ of HEPES; $2 \mathrm{mM}$ glutamine; $100 \mathrm{ug} / \mathrm{mL}$ penicillin, $100 \mathrm{U} / \mathrm{mL}$ streptomycin were also added). Cortex was then cut and dissociated by a 10-minute trypsin treatment. Then, 500,000 cortical cells were placed on 6-well Poly-D-Lysine-coated tissue culture plates and maintained in serum-free medium (medium component: neurobasal medium (Life Technologies) containing 1X B27 supplement (Life Technologies), $2 \mathrm{mM}$ glutamine, $100 \mathrm{ug} / \mathrm{mL}$ penicillin, $100 \mathrm{U} / \mathrm{mL}$ streptomycin).

Table 2 shRNA sequences used for knockdown experiments

\begin{tabular}{lccr}
\hline Gene & GenBank accession number & shRNA target sequence & TaqMan assay ID \\
\hline Mecp2 & NM_010788 & GCCGATCTGCTGGAAAGTATG & Mm00465017_m1 \\
Mef2a & NM_001033713 & GCCCTAATGCTTGTCGTACA & Mm00488963_m1 \\
Mef2d & NM_133665 & GTAGCTCTCTGGTCACTCC & Mm00504929_m1 \\
Nlgn1 & NM_138666 & GCAGATTGCCTGAAGTTATGC & Mm02344307_m1 \\
Nlgn3 & NM_172932 & GGATATGGTGGATTGTCTTCG & Mm01225953_m1 \\
Pten & NM_008960 & GGACAAGTTCATGTACTTTGA & Mm00477210_m1 \\
Shank3 & NM_021423 & GGGAGAAGTTGATGAGATCC & Mm00498775_m1 \\
Gapdh & NM_008084 & Not Applicable & 4352339E \\
Luciferase (pGL3-Basic) & U47295 & AATTCAGCGGGAGCCACCTGA & Not Applicable \\
\hline
\end{tabular}


Plate-randomized, quadruplicate cortical cultures were transduced at 2 days in vitro (DIV2) at an optimized MOI of 3.0. Lentiviral particles remained for 6 hours, after which, particles were removed and replaced with conditioned complete neurobasal medium. Cultures were allowed to mature for an additional 14 days post transduction (DIV16), at which time, total RNA was isolated (described below).

\section{Hairpin validation}

For each gene target, five unique shRNA targeting lentiviral constructs were generated as described above, along with an shRNA control (designed against luciferase), and used to produce small-scale lentiviral stocks. Viral stocks were used to transduce primary cortical neuronal cultures (see primary neuronal cultures and transduction methods) on DIV2 and cells were grown in culture an additional 7 to 10 days. Total RNA and protein were isolated from replicate cultures. Quantitative PCR (qPCR) (Figure 1) and western blot (Additional file 1: Figure S1) was performed to validate a minimum knockdown level of $75 \%$ at the mRNA (described below) and protein levels for all hairpin constructs used in study. Glyceraldehyde 3-phosphate dehydrogenase (Gapdh) levels were monitored at both the RNA and protein levels as a control. The best-performing hairpin for each gene was carried forward for genome-wide expression analysis.

\section{RNA isolation, CDNA synthesis and qPCR}

Total RNA was isolated utilizing the Qiagen (Germantown, MD, USA) RNeasy mini total RNA isolation kit according to manufacturer's instructions. RNA quality was validated utilizing a NanoDrop spectrophotometer (Thermo Fisher Scientific, Waltham, MA, USA), assuring at least a 2.0 260/280 ratio was obtained. cDNA was generated from 1 ug total RNA using the Life Technologies High Capacity RNA-to-cDNA kit (number 4390716) according to manufacturer's instructions. Prior to the Affymetrix (Santa Clara, CA, USA) Gene Chip analysis, qPCR for the target gene was performed on quadruplicate replicates 15 ngs RNA-equivalent cDNA to ensure knockdown. Only samples showing acceptable knockdown ( $>75 \%$ knockdown by mRNA) were submitted for gene chip analysis.

\section{Microarray hybridization and quality control analysis}

Total RNA was hybridized to Affymetrix Mouse 430_2 microarrays at Gene Logic (Gaithersburg, MD, USA). RNA degradation plots were analyzed for quality control purposes. Four samples did not pass quality control (QC) and were omitted from further analysis (one each from the Mef2d, Nlgn1, Shank3, and non-transduced groups). The raw data files were then normalized using robust multi-array averaging (RMA) [40]. Hierarchical clustering by positive correlation (Ward linkage) was performed in Genedata Expressionist. Prior to statistical analysis, probe sets with _x designations were excluded for potential lack of specificity. Additional probe sets were excluded if absolute expression was $<50$ for all samples (expression was considered absent), resulting in 24,343 probe sets for statistical analysis. Gene expression for all sample types was analyzed on the $\log 2$ scale. Linear models were used to calculate $P$-values between the groups of interest. The linear model $t$-statistics were regularized using the moderated- $t$ approach of Smyth [41]. Adjustment of

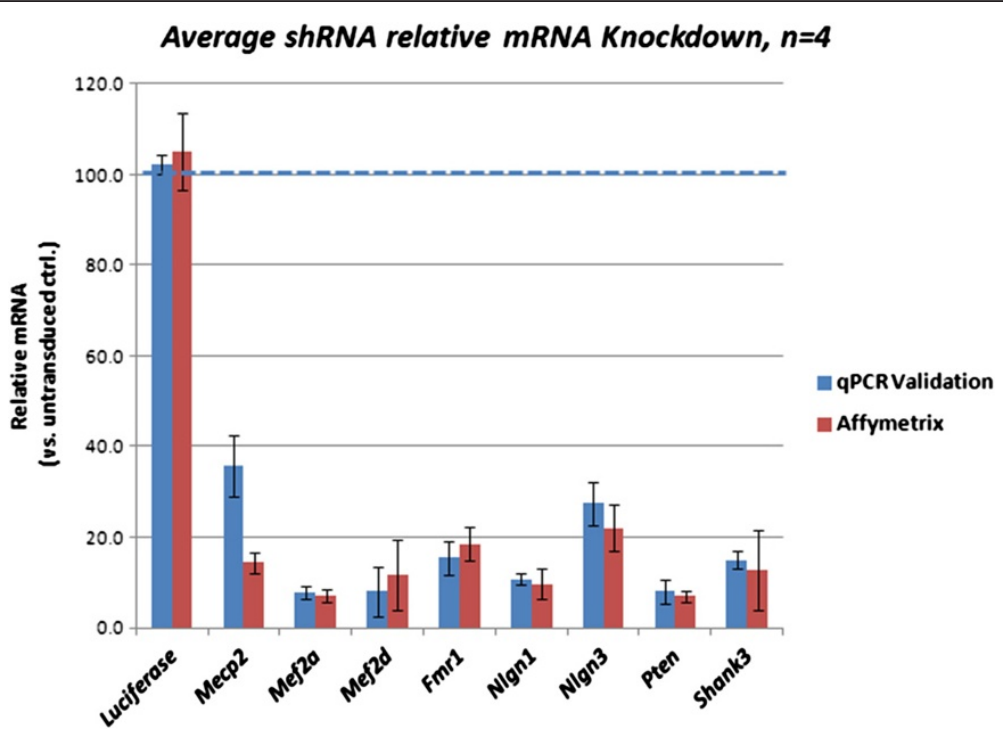

Figure 1 shRNA efficiently knocks down RNA levels of target genes. The bars representing the Luciferase-targeting control short-hairpin (sh) RNA-treated neuronal samples are the average values of all target genes. There was no significant difference between the untreated cells and Luciferase shRNA-treated cells for any of the targeted genes. 
$P$-values was performed according to Benjamini and Hochberg [42] to control for multiplicity of testing. Each set of microarrays from a shRNA experiment treatment group were compared to the set of microarrays from the luciferase shRNA control set. Probe sets with false discovery rate (FDR)-corrected $P$-value $\leq 0.05$ and $\geq 1.5$-fold change were identified for each treatment group for pathway analysis, as the historic RT-PCR confirmation rate of microarray data fitting these criteria is approximately 70\% (Additional file 2: Table S1). Overlap with a recently published autism gene interactome [20] was performed for all treatment groups. All primary microarray data from this experiment are available in the Gene Expression Omnibus [GEO:GSE47150].

\section{Bioinformatics analysis of gene expression data}

Analyses of gene lists from the miRNA experiments were performed using either Nextbio $^{\mathrm{mm}}$ software (Santa Clara, CA, USA, www.nextbio.com), Gene Sensor Suite (GSS), or the causal reasoning engine (CRE). The NextBio software uses a modified form of the gene set enrichment algorithm to identify important pathways and other ontologies [43]. All analyses done with NextBio were done utilizing the default parameters. NextBio pathway analysis utilized the pathways compiled by the Broad Institutes gene set enrichment analysis (GSEA) application as part of their molecular signatures database, MSigDB [44]. Related tissues were identified from NextBio's transcriptional profiles for over 6,000 publically available studies. The GSS application identifies significantly enriched pathways using Fisher's exact test and corrected for multiple testing using Q-value $[45,46]$. GSS pathways were generated from Ingenuity pathways from October 2010 (Ingenuity ${ }^{\oplus}$ Systems (Redwood City, CA, USA), www.ingenuity.com). The CRE algorithm uses multiple statistical parameters to assess the similarity to upstream effectors and their downstream responses to interpret measured gene expression changes $[47,48]$. Simply stated, the CRE can be thought of as an enhanced type of gene set enrichment analysis (GSEA). Causal statements were curated from the biomedical literature (Ingenuity and Selventa knowledge bases) in the form of, X (increases or decreases) Y, such that X and Y are measured biological quantities. These quantities can consist of multiple types, including protein modifications, mRNA levels, biological processes and/or chemical compound treatments. The combined knowledge base is then interrogated with the microarray transcriptomic data to infer upstream events (called hypotheses). The CRE algorithm generates statistical stringency by employing two primary methods. First, enrichment of all possible transcripts for the hypothesis is measured, a method shared in common with GSS and GSEA. Second, the method of correctness of the hypothesis is calculated, and is simply the difference of having the correct direction minus the incorrect transcripts observed. There are two advantages in using these methods in the CRE. The first advantage is that it is a specific molecular interaction of the hypothesis that is being evaluated. Second, the directionality of the interaction within the hypothesis is retained by using the correctness parameter. $P$-values were generated and cutoffs were applied using the following filters: correctness $P$-value $<0.05$, enrichment $P$-value $<0.05$, minimum number of correctly explained gene expression changes $\geq 3$, percent correctly explained gene expression changes $\geq 60 \%$, ranking score $<100$. The hypotheses were deciphered and visualized using the Causal Reasoning Browser, a Java-based plugin for the open source biomolecular interaction viewer Cytoscape (www.cytoscape.org)[49].

\section{BDNF quantitation}

Neurons were treated in 24-well plates with blank media or shRNA against luciferase, Fmr1, or Mecp2 in randomized wells across two plates ( $\mathrm{n}=12$ per condition). For protein analysis, neurons were lysed in $20 \mathrm{mM}$ Tris $\mathrm{HCl}$ (pH 7), $137 \mathrm{mM} \mathrm{NaCl}, 1 \% \mathrm{NP} 40,10 \%$ glycerol, $1 \mathrm{mM}$ PMSF, $10 \mu \mathrm{g} / \mathrm{mL}$ aprotinin, $1 \mu \mathrm{g} / \mathrm{mL}$ leupeptin, and 0.5 $\mathrm{mM}$ sodium orthovanadate. Lysates were centrifuged at $14,000 \times \mathrm{g}$ for 30 minutes at $4^{\circ} \mathrm{C}$. Supernatants were stored at $-80^{\circ} \mathrm{C}$ until assay. BDNF levels were measured using a modified version of the Promega (Madison, WI, USA) BDNF Emax ${ }^{\oplus}$ Immunoassay system (G7611). Half-volume 96-well ELISA plates (Costar; Corning, Lowell, MA, USA) were coated with $50 \mu \mathrm{l}$ anti-BDNF mAb at 1:1000 dilution in $0.025 \mathrm{M}$ sodium bicarbonate and $0.025 \mathrm{M}$ sodium carbonate, sealed, and stored at $4{ }^{\circ} \mathrm{C}$ overnight. Plates were washed four times with PBS containing 0.05\% Tween20, then blocked for 2 hours at room temperature with $130 \mu \mathrm{l} /$ well Promega blocking buffer (G3311). Samples and standards were prepared in blocking buffer (1:4 dilution), then loaded onto the plates $(50 \mu \mathrm{l})$ following a wash step. Plates were sealed and stored at $4{ }^{\circ} \mathrm{C}$. On the third day plates were washed and incubated with $50 \mu \mathrm{l} /$ well anti-human BDNF pAb at 1:500 dilution in blocking buffer for 2 hours at room temperature. Plates were washed again and incubated with $50 \mu \mathrm{l}$ anti-IgY horseradish peroxidase conjugate at 1:200 dilution in blocking buffer for 1 hour at room temperature. Following a final wash, $50 \mu \mathrm{l}$ TMB solution was added to each well. The reaction was stopped with $1 \mathrm{~N} \mathrm{HCl}$ after 10 minutes, and $450 \mathrm{~nm}$ optical densities were read on a Spectramax plate reader (Molecular Devices, Sunnyvale, CA, USA). Samples were interpolated off of a standard curve fit by a fourth order polynomial equation. Interpolated BDNF levels were normalized to total protein (DC Protein Assay Kit II, Bio-Rad, Hercules, CA, USA). GraphPad Prism 5.0 was used to perform the Kruskal-Wallis test followed by the Dunn test for multiple comparisons, to determine statistically significant changes $(P$-value $<0.05)$. 


\section{Results}

\section{Confirmation of knockdown}

Prior to transcriptomic analysis, individual RNA samples were confirmed for relative knockdown by quantitative RT-PCR. Average knockdown of replicate samples (Figure 1) for the candidate genes were as follows: Mecp2 (86\%), Mef2a (94\%), Mef2d (89\%), Fmr1 (86\%), Nlgn1 (89\%), Nlgn3 (89\%), Pten (95\%) and Shank3 (90\%). Knockdown was normalized to a single untransduced cortical neuronal sample (detected message levels were relative to Gapdh). All individual samples showed at least a 75\% knockdown of target gene expression providing high confidence that the pathways under investigation were being significantly perturbed. Additional experiments (Additional file 1: Figure S1) indicated that protein levels for all gene products were decreased in conjunction with lentiviral-mediated RNA knockdown in the primary neurons.

\section{Evaluation of differentially expressed genes}

Expression values for each of the shRNA-targeted genes as determined by the Affymetrix GeneChips correlated well with values determined by RT-PCR (Figure 1 - Affymetrix data from shRNA-treated samples were compared to the untransfected control for purposes of the figure). Hierarchical clustering of normalized data revealed tight correlation among biological replicates, with the exception of Mef $2 a$, in which one sample was separated from the rest (Figure 2). Pten was the most distinct treatment group, lying in its own branch of the tree. The next most isolated treatment group was with Mecp2 knockdown (Additional file 3: Table S2). These treatments produced the most numerous changes in gene expression amongst all the hairpins. The total number of probe sets identified as significantly different from the luciferase control $(>1.5$ fold at $P<0.05)$ in each condition were as follows: Fmr1 (2,395), Mef2d (2,736), Mef2a (1,059), Mecp2 (3,967), Nlgn1 (1,230), Nlgn3 (2,224), Pten (3,653), and Shank3 $(1,445)$. Comparison of the luciferase shRNA versus the untransduced control revealed the smallest number of significant changes - 997. As an early determination of the relevance of cell-culture knockdown to the known molecular biology of ASD, the current datasets were evaluated for enrichment in an ASD gene interactome established by Sakai et al. [20]. Although the luciferase versus blank condition was not significantly enriched for genes in this interactome, Fmr1, Mecp2, Mef $2 a, M e f 2 d$, Nlgn1, Pten, and Shank3 shRNA transcriptomes all showed significant overlap (Table 3 ). The most frequently identified ASD interactome gene was $C A M K 2 A$, which was upregulated by Fmr1 shRNA, but downregulated by all of the other ASD gene shRNA targets.

\section{NextBio detection of related transcriptional profiles}

The Nextbio database allows for comparison of transcriptional profiles between datasets and transcriptional profiles for over 6,000 publically available studies. The most highly correlated datasets for any of the ASD gene shRNA profiles were other ASD shRNA profiles from this experiment. As a control, the $M e f 2 a$ and $M e f 2 d$ profiles were compared against a published study in which the same hippocampal neurons were transduced with both $M e f 2 a$ and $M e f 2 d$ [32]. The published study showed significant positive correlation with the present $M e f 2 a$ and $M e f 2 d$ datasets, with 107 genes in common with $M e f 2 a$ profile and 283 genes in common with the Mef $2 d$. Similarly, a comparison with microarray analysis of cortex from Mecp 2 knockout mice showed significant overlap with this Mecp2 shRNA transcriptional profile (445 genes in common, $P=1 \times 10^{-8}$ ) [6]. The most highly correlated publically available transcriptional profiles for the remaining ASD-related genes came from comparisons of mouse brains at various postnatal ages to embryonic day 14.5 [50] or up to birth [51]. A time course of primary mouse hippocampal neurons in vitro [52] was also correlated with all shRNA treatments (data not shown). All of these developmental datasets showed significant inverse correlation with all shRNA treatments, including luciferase. Given the number of activity-dependent genes affected by shRNA treatment, the correlations with developmental datasets suggest that lentiviral gene delivery may have nonspecifically altered the development of the mouse neurons. Therefore, care was taken to subtract any changes observed in the lentiviral-treated cells from the other datasets for all analyses in an attempt to minimize the impact of this potential artifact.

\section{Pathway analysis}

NextBio analysis of the MSigDB pathways yielded a large number of canonical pathways significantly enriched in one or more treatment group. Three of these pathways were significantly enriched in the luciferase versus blank comparison but not in any other dataset. In addition, the luciferase versus blank dataset yielded a number of pathways in common with other shRNA datasets. These pathways were considered nonspecific and excluded from further analysis. After excluding these pathways, 256 canonical pathways were significantly enriched in one or more treatment groups. Many of these pathways were affected by more than one condition; 26 pathways were significantly enriched by 5 or more ASD shRNA datasets and the top 15 most conserved are shown in Table 4. The most frequently enriched pathway was the Neurotrophic tyrosine kinase receptor type $1(\operatorname{Trk} A)$ receptor pathway, in which all datasets had a significant number of downregulated genes except Pten, which had a significant number of upregulated genes. Other pathways affected by multiple ASD gene shRNA targets included signaling pathways related to additional genes implicated in ASD, such as Neuregulin, Mammalian Target Of Rapamycin (mTOR), and Reelin. 


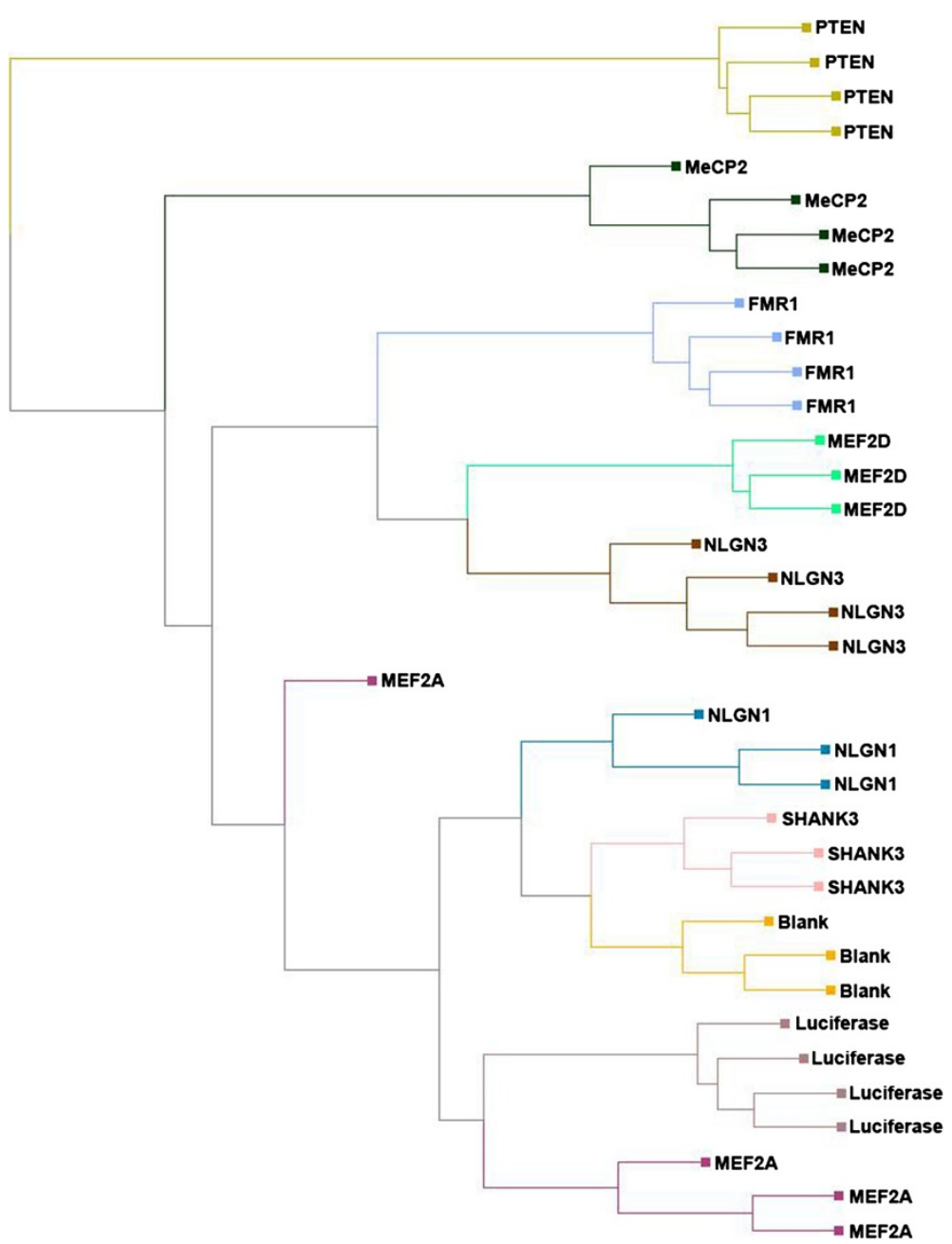

Figure 2 Hierachical clustering of intensity values from individual short-hairpin (sh)RNA knockdown experiments.

ASD gene count, number of conditions in which the pathway was significantly affected (that is, the number of different shRNAs that altered that particular pathway); Up, numbers of member genes altered in each pathway at least 1.5-fold broken out by positive fold-changes; Down, numbers of member genes altered in each pathway at least 1.5-fold broken out by negative fold-changes; ASD, autism spectrum disorder; NFKB, Nuclear factor KB; TrkA, Neurotrophic tyrosine kinase receptor type 1; PGC1A, Peroxisome proliferator-activated receptor gamma coactivator 1-A ERBB3, Receptor tyrosine-protein kinase erbB-3.

GenSensor analysis of the Ingenuity pathways resulted in 114 canonical pathways which were significantly overrepresented in one or more of the ASD shRNA treatment groups. The top fifteen most conserved pathways are show in Table 5 (see Additional file 4: Table S3 for the complete list). In the pathways found only in the ASD shRNA treated samples, there are a number of pathways related to neuronal signaling, in particular to cyclic AMP signaling. Thirteen of these pathways were significantly enriched in the luciferase versus blank comparison (yellow highlighted). These pathways may indicate general effects of the shRNA delivery system on the neuron cell culture. However, because GSS does not consider the magnitude of gene expression change, these results do not preclude real treatmentrelated effects on these pathways above the background levels induced by the lentivirus. Only two pathways were found to be enriched solely in the luciferase versus blank comparison.

Numbers are odds ranking of the pathways in each shRNA experiment. All pathways were sorted by number of shRNA experiments in which they appear (high to low) followed by average ranking in experiments (low to high). Italicized pathways were also enriched in the luciferase control experiment. GNRH, gonadotrophin-releasing hormone; THOP, Thimet oligopeptidase 1; NFAT, Nuclear factor of activated T-cells. 
Table 3 Autism spectrum disorder interactome genes significantly altered by three or more shRNA treatments

\begin{tabular}{|c|c|c|c|c|c|c|c|c|c|}
\hline \multirow[t]{2}{*}{ Gene } & \multirow[t]{2}{*}{ Gene description } & \multicolumn{8}{|c|}{ Fold-change } \\
\hline & & Fmr1 & Mecp2 & Mef2a & Mef2d & Nlgn 1 & Nlgn3 & Pten & Shank3 \\
\hline Camk2a & Calcium/calmodulin-dependent protein kinase II alpha & 1.69 & -2.00 & -1.81 & -1.65 & -1.85 & -1.68 & -2.53 & -1.68 \\
\hline Prmt1 & Protein arginine $\mathrm{N}$-methyltransferase 1 & 1.55 & 2.32 & & 2.02 & 1.65 & 2.17 & 1.79 & 2.06 \\
\hline Cacnalc & Calcium channel, voltage-dependent, L-type, alpha 1C subunit & 1.68 & 1.75 & 1.69 & 1.90 & 1.64 & 1.67 & 2.23 & \\
\hline Sh3gl3 & SH3-domain GRB2-like 3 & & 1.59 & 1.70 & 1.62 & 1.59 & 1.63 & 1.84 & 1.56 \\
\hline R3hdm 1 & R3H domain 1 (binds single-stranded nucleic acids) & 2.40 & -2.09 & -1.63 & 1.92 & & -1.65 & -1.88 & \\
\hline Tgfblit & Transforming growth factor beta 1-induced transcript 1 & & & & -2.96 & 1.74 & -3.19 & 2.48 & \\
\hline Lims2 & LIM and senescent cell antigen-like domains 2 & & 2.43 & & 1.75 & & & 3.80 & 1.90 \\
\hline Kif17 & Kinesin family member 17 & -2.01 & -2.13 & & -2.36 & & -1.70 & & \\
\hline Nkd2 & Naked cuticle 2 homolog (Drosophila) & -1.78 & -2.12 & & -1.83 & & -1.77 & & \\
\hline Capn3 & Calpain 3 & & -1.65 & 1.53 & 2.98 & & & -1.77 & \\
\hline Nell1 & NEL-like 1 (chicken) & 2.23 & -1.85 & & -1.58 & 1.64 & & & \\
\hline PYCR1 & Pyrroline-5-carboxylate reductase 1 & -1.56 & -2.81 & & & & -2.00 & 1.55 & \\
\hline TBC1D9B & TBC1 domain family, member 9B (with GRAM domain) & 1.94 & -2.08 & 1.57 & & & & 1.50 & \\
\hline Prr13 & Proline-rich 13 & -1.81 & -1.77 & & -1.71 & & -1.82 & & \\
\hline STK32C & Serine/threonine kinase $32 \mathrm{C}$ & & -1.89 & & & & -1.64 & -1.69 & -1.51 \\
\hline DLGAP2 & Discs, large (Drosophila) homolog-associated protein 2 & 1.80 & & -1.60 & & -2.10 & & & \\
\hline SOD1 & Superoxide dismutase 1 , soluble & & & -1.64 & & & & -2.22 & -1.69 \\
\hline Dlgap1 & Discs, large (Drosophila) homolog-associated protein 1 & 1.91 & & & -2.45 & & & -1.86 & \\
\hline MBD2 & Methyl-CpG binding domain protein 2 & & & -1.94 & & & -1.58 & & -1.55 \\
\hline FBLN5 & Fibulin 5 & 1.52 & 2.15 & & & & & 2.69 & \\
\hline Sertad1 & SERTA domain-containing 1 & & & & -1.67 & & -1.95 & & -1.69 \\
\hline Bhlhe40 & Basic helix-loop-helix family, member e40 & & -2.28 & & -1.85 & & -1.74 & & \\
\hline Slit2 & Slit homolog 2 (Drosophila) & & -1.68 & & -2.43 & & & -2.09 & \\
\hline Actn2 & Actinin alpha 2 & & -2.64 & & -1.53 & & -1.65 & & \\
\hline Ube3a & Ubiquitin protein ligase E3A & & -2.48 & & -1.52 & & & & -1.53 \\
\hline S/c13a3 & $\begin{array}{l}\text { Solute carrier family } 13 \text { (sodium-dependent dicarboxylate transporter), } \\
\text { member } 3\end{array}$ & & & & 2.32 & & 1.56 & -1.60 & \\
\hline NOMO1 & NODAL modulator 1 & & & 1.64 & & & & 1.53 & 1.54 \\
\hline RALBP1 & RalA binding protein 1 & 1.65 & & 1.52 & & & & 1.73 & \\
\hline MYH10 & Myosin, heavy chain 10 , non-muscle & -2.12 & -1.78 & & & & & -1.53 & \\
\hline HMG20A & High-mobility group $20 \mathrm{~A}$ & & 1.68 & 1.59 & & & & 1.76 & \\
\hline BAIAP2 & BAl1-associated protein 2 & & & & & -1.51 & -1.73 & -1.55 & \\
\hline Fxr1 & Fragile $\mathrm{X}$ mental retardation gene 1 , autosomal homolog & 1.61 & 1.56 & & 1.99 & & & & \\
\hline Lingo 1 & Leucine-rich repeat and Ig domain-containing 1 & & & & -1.56 & & & -1.73 & -1.57 \\
\hline Nup62 & Nucleoporin 62 & -1.54 & & & -1.59 & & -1.70 & & \\
\hline Notch2 & Notch gene homolog 2 (Drosophila) & & 1.69 & & 1.52 & & & -2.06 & \\
\hline EML1 & Echinoderm microtubule-associated protein-like 1 & -1.64 & 1.72 & & & & & -1.72 & \\
\hline NECAB3 & N-terminal EF-hand calcium-binding protein 3 & & -1.79 & & & & -1.52 & -1.75 & \\
\hline Tcf25 & Transcription factor 25 (basic helix-loop-helix) & & & & -1.51 & & -1.69 & -1.54 & \\
\hline
\end{tabular}

Causal reasoning engine - molecular network inferences CRE analysis yielded a large number of causal hypotheses for each ASD shRNA treatment group. The rank order for the hypotheses was as follows: Mecp2 (218) > Mef2d (216) > Nlgn3 (174) > Mef2a (170) > Nlgn1 (151) > Shank3 (82) > Fmr1 (45) > Pten (12). The top fifteen hypotheses 
Table 4 Canonical pathways in NextBio that were significantly enriched following ASD gene-targeted shRNA constructs, but not affected by luciferase shRNA

\begin{tabular}{|c|c|c|c|c|c|c|c|c|c|c|c|c|c|c|c|c|c|}
\hline \multirow[b]{2}{*}{ Biogroup } & \multirow{2}{*}{$\begin{array}{l}\text { ASD gene } \\
\text { count }\end{array}$} & \multicolumn{2}{|c|}{ Fmr1 } & \multicolumn{2}{|c|}{ Mecp2 } & \multicolumn{2}{|c|}{ Mef2a } & \multicolumn{2}{|c|}{ Mef2d } & \multicolumn{2}{|c|}{ Nlgn1 } & \multicolumn{2}{|c|}{ Nlgn3 } & \multicolumn{2}{|c|}{ Pten } & \multicolumn{2}{|c|}{ Shank3 } \\
\hline & & Up & Down & Up & Down & Up & Down & Up & down & Up & Down & Up & Down & Up & Down & Up & Down \\
\hline TrkA receptor & 8 & & 2 & & 4 & & 2 & & 2 & & 2 & & 3 & 3 & & & 2 \\
\hline Erythropoietin-mediated neuroprotection through NFKB & 7 & 3 & 2 & & 3 & & 3 & & 1 & & 2 & & 1 & 3 & & & \\
\hline PGC1A pathway & 7 & & & & 8 & & 5 & & 7 & & 3 & & 4 & & 9 & & 4 \\
\hline Long-term potentiation & 7 & 8 & & & 18 & & 5 & & 15 & 3 & & & & & 16 & & 6 \\
\hline Cell adhesion molecules (CAMs) & 7 & & & 10 & 14 & & 8 & & 13 & & 8 & & 11 & 13 & 12 & & 10 \\
\hline G2 and $M$ phases & 7 & & 1 & & 1 & & 1 & 1 & 1 & & 1 & & 2 & 3 & & & \\
\hline P53 HYPOXIA pathway & 7 & & 3 & & 3 & & 3 & & 3 & & 2 & & 3 & 6 & & & \\
\hline Biosynthesis of steroids & 6 & & 8 & & 5 & & & & 3 & 2 & & & 5 & & 4 & & \\
\hline Arginine and proline metabolism & 6 & & 8 & & 9 & 1 & & & 8 & & & & 8 & 5 & & & \\
\hline Antigen processing and presentation & 6 & & & & 9 & & 3 & & 6 & & 3 & & 10 & & & & 4 \\
\hline BAD pathway & 6 & & 3 & & & & 3 & & 4 & 2 & & 2 & & & & & 2 \\
\hline $\begin{array}{l}\text { Neuroregulin receptor degredation protein-1 controls ERBB3 receptor } \\
\text { recycling }\end{array}$ & 6 & & & 1 & & 1 & & 1 & & 1 & & 1 & & & & 1 & \\
\hline Eicosanoid synthesis & 6 & & & & & & 1 & & 1 & & 1 & & 1 & 3 & & & 2 \\
\hline Phosphatidylinositol signaling system & 5 & 10 & & & 17 & & & & & & 6 & & 11 & & 10 & & \\
\hline Vitamin B6 metabolism & 5 & 1 & & & 3 & & & 1 & 1 & & & 1 & 2 & & 1 & & \\
\hline
\end{tabular}


Table 5 Ingenuity pathways that were significantly enriched in multiple ASD short-hairpin (sh)RNA knockdown experiments

\begin{tabular}{|c|c|c|c|c|c|c|c|c|c|c|c|}
\hline Description & $\begin{array}{c}\text { Blank } \\
\text { pathway } \\
\text { ranking }\end{array}$ & $\begin{array}{c}\text { Fmr1 } \\
\text { pathway } \\
\text { ranking }\end{array}$ & $\begin{array}{c}\text { Mef2a } \\
\text { pathway } \\
\text { ranking }\end{array}$ & $\begin{array}{c}\text { Mef2d } \\
\text { pathway } \\
\text { ranking }\end{array}$ & $\begin{array}{c}\text { Mecp2 } \\
\text { pathway } \\
\text { ranking }\end{array}$ & $\begin{array}{c}\text { Nlgn1 } \\
\text { pathway } \\
\text { ranking }\end{array}$ & $\begin{array}{c}\text { Nlgn3 } \\
\text { pathway } \\
\text { ranking }\end{array}$ & $\begin{array}{c}\text { Pten } \\
\text { pathway } \\
\text { ranking }\end{array}$ & $\begin{array}{c}\text { Shank3 } \\
\text { pathway } \\
\text { ranking }\end{array}$ & $\begin{array}{l}\text { Pathway } \\
\text { count }\end{array}$ & $\begin{array}{l}\text { Average } \\
\text { ranking }\end{array}$ \\
\hline Axonal guidance signaling & 4 & 1 & 16 & 2 & 1 & 2 & 1 & 4 & 1 & 8 & 3.50 \\
\hline Molecular mechanisms of cancer & 6 & 5 & 2 & 11 & 6 & 1 & 2 & 1 & 6 & 8 & 4.25 \\
\hline Breast cancer regulation by stathmin 1 & 13 & 8 & 1 & 8 & 4 & 3 & 5 & 2 & & 7 & 4.43 \\
\hline G-protein coupled receptor signaling & & 2 & 10 & 5 & 8 & & & 9 & & 5 & 6.80 \\
\hline Protein kinase A signaling & & 6 & & 18 & 2 & & 14 & 3 & & 5 & 8.60 \\
\hline Huntington's disease signaling & & & 23 & 1 & 37 & & & 22 & 3 & 5 & 17.20 \\
\hline Corticotropin-releasing hormone signaling & & & 4 & 9 & 31 & & 7 & 36 & & 5 & 17.40 \\
\hline Calcium signaling & 8 & & 15 & 12 & 44 & & & 43 & 11 & 5 & 25.00 \\
\hline Amyotrophic lateral sclerosis signaling & & 4 & & 15 & 66 & & & 41 & 7 & 5 & 26.60 \\
\hline Synaptic long-term potentiation & & & 5 & 6 & 5 & & & 6 & & 4 & 5.50 \\
\hline CAMP-mediated signaling & & & 8 & 7 & 3 & & & 7 & & 4 & 6.25 \\
\hline GNRH signaling & & & 6 & 20 & 9 & & & 13 & & 4 & 12.00 \\
\hline Neuropathic pain signaling in dorsal horn neurons & & 7 & 21 & 3 & & & & 18 & & 4 & 12.25 \\
\hline Neuroprotective role of THOP1 in Alzheimer's disease & 7 & 23 & 19 & & & 4 & 6 & & & 4 & 13.00 \\
\hline Role of NFAT in cardiac hypertrophy & & & & 17 & 7 & & 9 & 19 & & 4 & 13.00 \\
\hline
\end{tabular}




\begin{tabular}{|c|c|c|c|c|c|c|c|c|c|c|}
\hline & blank & MeCP2 & Mef2a & Mef2d & NLGN1 & NLGN3 & Shank3 & Fmr1 & Pten & $\begin{array}{c}\text { number of } \\
\text { experiments }\end{array}$ \\
\hline \multicolumn{11}{|l|}{ hypothesis name } \\
\hline STAT4 $(-)$ & & & & & & & & & & 7 \\
\hline $\operatorname{socs} 2(+)$ & & & & & & & & & & 7 \\
\hline potassium chloride (-) & & & & & & & & & & 7 \\
\hline PARP1 (-) & & & & & & & & & & 7 \\
\hline NLRP12 (-) & & & & & & & & & & 7 \\
\hline IL2 (-) & & & & & & & & & & 7 \\
\hline cancer (-) & & & & & & & & & & 7 \\
\hline bucladesine $(-)$ & & & & & & & & & & 7 \\
\hline response to UV (-) & & & & & & & & & & 6 \\
\hline response to hypoxia $(-)$ & & & & & & & & & & 6 \\
\hline PTH (-) & & & & & & & & & & 6 \\
\hline propranolol (+) & & & & & & & & & & 6 \\
\hline PROK1 (-) & & & & & & & & & & 6 \\
\hline phorbol esters (-) & & & & & & & & & & 6 \\
\hline norepinephrine (-) & & & & & & & & & & 6 \\
\hline kainic acid (-) & & & & & & & & & & 6 \\
\hline isoproterenol (-) & & & & & & & & & & 6 \\
\hline Ischemia (-) & & & & & & & & & & 6 \\
\hline HDAC1 $(+)$ & & & & & & & & & & 6 \\
\hline GDNF (-) & & & & & & & & & & 6 \\
\hline experimental stroke $(-)$ & & & & & & & & & & 6 \\
\hline ESR1 (-) & & & & & & & & & & 6 \\
\hline CSF1 (-) & & & & & & & & & & 6 \\
\hline CRH (-) & & & & & & & & & & 6 \\
\hline CHR-2797 (-) & & & & & & & & & & 6 \\
\hline cerivastatin (-) & & & & & & & & & & 6 \\
\hline camptothecin (-) & & & & & & & & & & 6 \\
\hline 1-methyl-4-phenyl-1,2,3,6-tetrahydropyridine (-) & & & & & & & & & & 6 \\
\hline 1-alpha, 25-dihydroxy vitamin D3 (-) & & & & & & & & & & 6 \\
\hline $\begin{array}{l}\text { Figure } 3 \text { Diverse set of ASD-associated } \mathbf{g} \\
\text { hypotheses were observed in at least three } \\
\text { treatment conditions are included in the fig } \\
\text { Additional file } 5 \text { : Table } S 4 \text { list contains a full } \\
\text { and (-) indicates it is predicted to be down }\end{array}$ & $\begin{array}{l}\text { oroduc } \\
\text { experin } \\
\text { d squar } \\
\text { he } 269 \\
\text { ed. Nar }\end{array}$ & $\begin{array}{l}\text { similar } \\
\text { nts and } \\
\text { indicat } \\
\text { ypothes } \\
\text { s highli }\end{array}$ & $\begin{array}{l}\text { athway- } \\
\text { lot in th } \\
\text { that the } \\
\text { s. The n } \\
\text { hted in }\end{array}$ & $\begin{array}{l}\text { evel pe } \\
\text { blank. } \\
\text { nypothe } \\
\text { ation (- } \\
\text { ange a }\end{array}$ & $\begin{array}{l}\text { urbatio } \\
\text { ly the } \\
\text { s was ic } \\
\text { indicat } \\
\text { part of }\end{array}$ & $\begin{array}{l}\text { Is when } \\
\text { ypothes } \\
\text { entified } \\
\text { the hy } \\
\text { he mole }\end{array}$ & $\begin{array}{l}\text { knockec } \\
\text { s that we } \\
\text { or that ex } \\
\text { othesis i } \\
\text { cular inte }\end{array}$ & $\begin{array}{l}\text { down } \\
\text { e obse } \\
\text { erime } \\
\text { predic } \\
\text { action }\end{array}$ & $\begin{array}{l}\text { total } \\
\text { d in a } \\
\text { I cond } \\
\text { to be } \\
\text { work }\end{array}$ & $\begin{array}{l}269 \\
\text { east } 6 \text { of the } \\
\text { on). } \\
\text { pregulated, } \\
\text { gure 4). }\end{array}$ \\
\hline
\end{tabular}

shared between the highest number of experiments is shown in Figure 3 (See Additional file 5: Table S4 for the complete list). There was no hypothesis that was seen in all eight experimental conditions and not in the blank. Looking at the experiments broadly, two groups emerge based on the conservation. Mecp2, Mef2d, Nlgn3, Mef2a, Nlgn1 and Shank3 share similar hypotheses and were more dynamic, generating 3 to 5 times more hypotheses. In contrast, the same hypotheses are not seen being implicated for the Fmr1 and Pten experiments, with the latter experiment appearing quite different than the rest. The predicted hypotheses are overwhelmingly downregulated, with $86 \%$ (230 of 268) with the respective order of contribution being 87\% (Mecp2), 89\% (Mef2d), 84\% (Nlgn3), 86\% (Mef2a), 87\% (Mef2a), 76\% (Nlgn1), and 79\% (Fmr1); Pten again is the exception with only $58 \%$. Figure 4 is a composite of the most conserved hypotheses generated by CRE for the seven concordant treatment groups. Recurring hypotheses are highlighted with circles. The central hubs of the network are cyclic AMP and the extracellular signal-regulated kinase (ERK) $1 / 2$ family, which are directly connected to seven and eight primary hypotheses respectively.

\section{Confirmation of BDNF protein response}

Given that multiple hypotheses predicted from multiple target-knockdown datasets converge on $B d n f$, regulation of $B d n f$ could play a central role in ASD pathobiology. In order to confirm that these predicted changes in BDNF were accurate and that the transcriptional changes measured translated to the protein level, the two shRNA conditions in which Bdnf mRNA was most robustly altered (Fmr1 and Mecp2) were evaluated for impacts on BDNF protein. Neurons were treated in the same manner as for the microarray study, and lysates were harvested and analyzed by ELISA for BDNF. As predicted by mRNA levels, the luciferase shRNA construct alone significantly lowered BDNF ( $P$-value $<0.05$ ) (Figure 5). Mecp2 shRNA further reduced BDNF levels, while Fmr1 shRNA significantly increased BDNF levels relative to luciferase shRNA $(P$-value $<0.05)$.

\section{Discussion}

ASD is a neurological disorder with a strong genetic component that has been linked to a number of gene defects. These genes have a broad range of activities, ranging from membrane receptors and scaffold proteins 


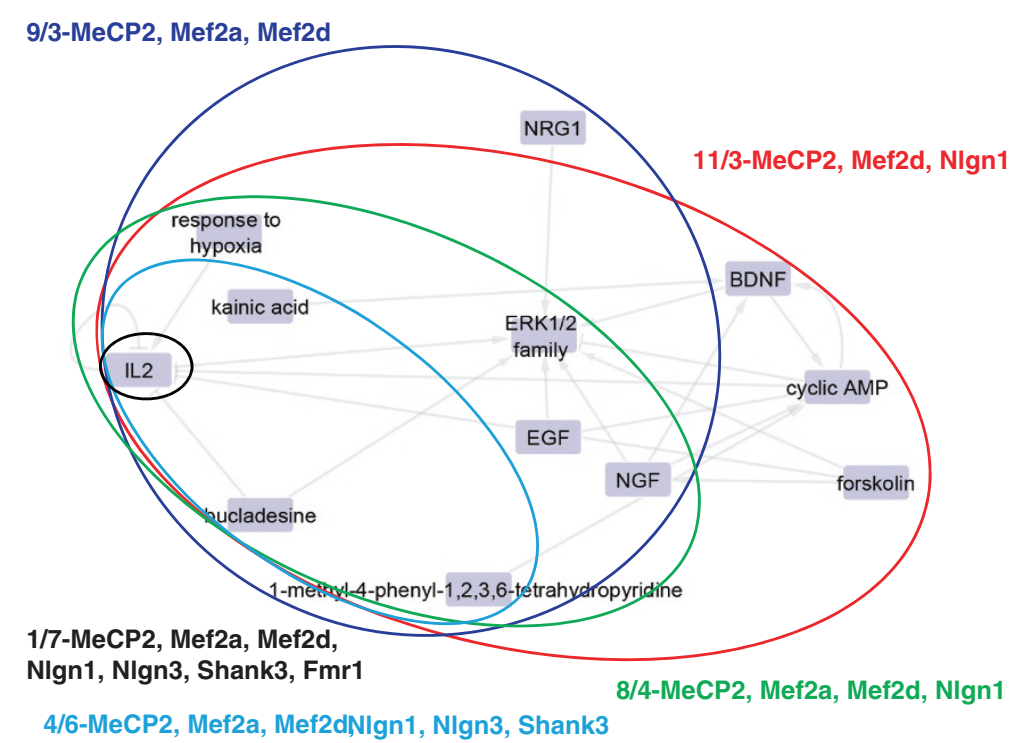

Figure 4 Multiple causal reasoning engine (CRE)-predicted hypotheses collapse into a molecular interaction network. The edges of the connections represent the information linking the nodes, for example, a PubMed reference for the interaction. The hypotheses are colored based on the direction of regulation: blue nodes are predicted down, whereas yellow are predicted up. Circled regions indicate significant hypotheses seen in different short-hairpin (sh)RNA experiments: red - Myocyte enhancer factor (Mef)2d, Methyl-CpG binding protein (Mecp)-2, Neuroligin (Nlgn1); blue - Mef2a, Mef2d, Mecp2; green - Mef2a Mef2d, Mecp2, NgIn1; light blue - Mecp2, Mef2a, Mef2d, Nlgn1, NIgn3, SH3 and multiple ankyrin repeat domains (Shank)3; black - Mecp2, Mef2a, Mef2d, Nlgn1, Nlgn3, Shank3, Fragile X mental retardation (Fmr)1 (IL2-hypothesis).

to metabolic regulators and transcription factors [25,35]. Despite this diversity, ASD patients manifest with similar behavioral and neuronal phenotypes, albeit with different severities. This commonality of neurological phenotype suggests that the genetic defects may act through a limited set of pathways. In this report, we employed shRNA knockdown of eight ASD relevant genes in neuronal culture to explore the downstream effects and identify common pathways or transcriptional signatures.

Following microarray analysis of all samples, we performed cluster analysis on the intensity values. As expected, samples clustered by treatment group, demonstrating an overall consistency and quality of the knockdown experiment and subsequent gene expression quantitation. It also illustrates the distinctiveness of the downstream expression effects of knockdown of individual genes. Knockdown of Pten and Mecp2 had the most dramatic effects on gene expression. Given Pten's broad role in numerous cellular processes and Mecp2's role as a transcription factor, these results were not unexpected. For example, mutations in Pten have been linked not only to ASD but also cancer and diabetes [53,54]. Fragile X mental retardation protein (FMRP), the protein product of Fmrl, has been shown to interact with a larger number of target proteins in relation to dendritic control of translation. A list of FMRP target proteins showed significant enrichment in the transcriptional profiles of shRNA for not only Fmr1, but also Mecp2, Pten, Shank3, Nlgn1 and Nlgn3 [25]. We further compared the genes affected in one or more knockdown experiments to a list of ASD interactome genes
[20]. This comparison indicated that knockdown of the eight ASD genes resulted in changes to a significant number of ASD interactome genes and the genes affected by the luciferase shRNA condition had little overlap with the ASD genes (Table 3). This control comparison is important, as other groups have reported nonspecific adverse effects of other shRNA and siRNA constructs $[55,56]$. The luciferase shRNA versus untransduced comparison yielded almost 1,000 differentially expressed transcripts, with an impact on BDNF measured at the protein level. Thus, by identifying the changes in the luciferase shRNA versus untransduced experiments and subtracting those, the subsequent pathway analyses could focus on pathways that were specifically targeted by knockdown of the ASD-relevant genes and not identify artifacts of the transduction.

We next analyzed the gene lists from the shRNA experiments by two pathway analysis approaches to obtain different perspectives on the data. The most prominent pathways revealed through analysis with NextBio were a number of pathways related to neurologic signaling and function (Table 4). Secondarily, NextBio indicated that several pathways involved general cellular metabolism and growth were also affected. One prominent pathway, the Peroxisome proliferator-activated receptor gamma coactivator 1-A (PGC1A) pathway, is based on the MSigDB's version of BioCarta's pathway and contains $M e f 2 A$ and several calcium-dependent kinases, which show gene expression changes in all shRNA experiments. One aspect of the NextBio analysis is that directionality of change 


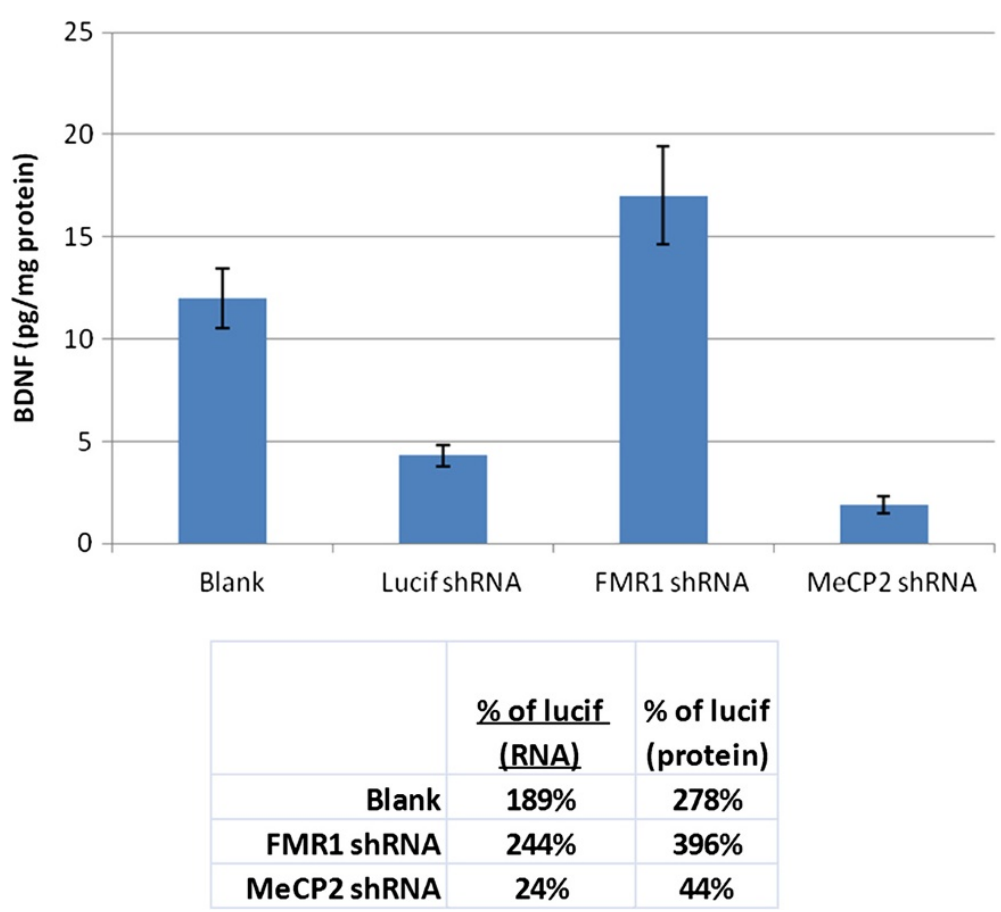

Figure 5 Measurement of BDNF protein levels in 14-days-in vitro mouse cortical neurons following transduction with short-hairpin (sh) RNA constructs for luciferase (non-mammalian control), Fragile X mental retardation (Fmr1), Methyl-CpG binding protein (Mecp2) or non-transduced neurons (blank). Values for mRNA and protein as \% of luciferase control shRNA are shown in the table on the right ( $n=12$ per group).

(that is, upregulated or downregulated) is reported. The majority of the pathways are downregulated with ASD shRNA knockdown, suggesting that the genes we chose for this work are needed for the expression of these pathways and thereby their activity. Pathway analysis with GenSensor also identified a number of pathways related to neuronal signaling and function (Table 5). As with the NextBio analysis, several growth and metabolism pathways were also affected.

During an examination of the individual pathways identified by the two pathway analysis methods, we noted a recurring involvement of the mitogen-activated protein kinase kinase (MEK)/ERK signaling pathway. These effects would occur either directly through a kinase signaling cascade (downstream of BDNF/TRK) or via cAMP (as in the case of the dopamine and serotonin G-protein coupled receptors). To further investigate this potential commonality, we employed CRE analysis to identify potential underlying mechanisms (CRE hypotheses) in the shRNA datasets. Unlike pathway analysis, which identifies pathways with altered gene expression, CRE analysis predicts potential mechanisms behind gene changes based on the concordance of the number of genes that change expression, and the directionality of that change [47]. The results of CRE analysis are interlinked hypotheses of potential driving mechanisms or experimental treatments that exhibit similar gene changes.
It is interesting that three of the eight most conserved hypotheses have a biological function suggestive of growth and/or immune function, suggesting similar driving mechanisms (Figure 3). Likewise, there are highly conserved hypotheses involved with neurogenesis, synaptic activity and differentiation, as expected, although not mutually exclusive. Choosing the Mef $2 d$ experiment as a representative of the six most conserved shRNA treatments, the top ranking clusters can be connected as a molecular interaction map with (Figure 4), cyclic AMP and ERK serving as dual hubs of the network directly connecting seven and eight related hypotheses respectively. Three of the experiments, Mecp2, Mef2d, and Nlgn1, shared 11 of the 12 hypotheses in the network. As more experiments are included, the shared number of hypotheses decreases, for example, the light blue grouping of six experiments including Shank3 is based on four hypotheses.

In addition to this work, other work directly or indirectly supports a role for ERK signaling in the development of ASD. For example, maternal use of one of several different classes of drugs relevant to ERK modulation has been reported to increase the risk of having children born with ASD [57]. Cocaine use during pregnancy has been reported to increase the rate of autism by $11 \%$. Cocaine use has also been shown to alter dopamine-induced phosphorylation of ERK via cAMP [58,59]. Recently, Hoffmann et al. showed that chronic cocaine use in rats 
can lead to attenuated ERK signaling [60]. Chronic maternal cocaine use might thereby attenuate ERK signaling in the fetus. Similarly, mothers taking valproic acid, an inhibitor of gamma-aminobutyric acid (GABA) function, have been demonstrated to have an increased risk of have children with autism [61]. As with cocaine, valproic acid activates ERK signaling [62]. Zou et al. demonstrated that RAS/RAF/ERK1/2 signaling was upregulated in the brains of the BTBR mouse model of autism [63]. Recently, the upregulation of this pathway (and of ERK5) has been shown to occur in the brains of autistic subjects [64]. Although misregulation of ERK does appear to be a common feature of ASD, the observed directionality of that misregulation has been contradictory. In the case of Rett syndrome, ERK signaling through the BDNF pathway in particular is reduced. BDNF levels are reduced in Mecp2-null mice, and exogenous BDNF has been shown to rescue deficits due to Mecp2 deficiency [7,9]. In human Rett syndrome patients, a Val/Met polymorphism in BDNF has been associated with disease severity [18]. In the present study, Mecp2 shRNA produced a significant reduction in $B d n f$ at both the mRNA and protein level, both of which were inversely affected by Fmr1 knockout. Given the diverse functions of BDNF in neurons, it would be interesting to determine in follow-up studies whether inverse functional outcomes may be observed with these treatments.

Based on the experimental data presented here and previously existing data, we have put together a pathway model to show that the transcriptional regulation exerted by a diverse set of ASD-associated genes converges on ERK signaling. A central role for ERK signaling would explain many of the features associated with ASD. Early work on the ERK proteins described these as microtubuleassociated protein 2 kinases, and were shown to phosphorylate MAP2 kinases, proteins known to be involved in neuronal architecture [65-67]. Later work demonstrated that ERK plays a critical role in microtubule formation and thereby to axon/dendrite formation [68,69]. A review article by Hoogenraad and Akhmanova has summarized the criticality of microtubules in synaptic plasticity [70]. Mutations that lead to altered ERK activity would then be expected to have alterations in axon extension and/or retraction and thereby, synaptic plasticity. Mazzucchelli et al. found that ERK1-knockout mice exhibit enhanced synaptic plasticity, most likely through the compensatory activation of ERK2 [71]. Voineagu et al. recently reported that the expression differences between the temporal and frontal lobes are significantly attenuated in individuals with autism [22]. They further suggested that this lack of differentiation is the mechanism behind the lack of long-range axonal connections and the decreased myelin thickness in autistic prefrontal lobes as reported by Zikopoulos and Barbas $[21,22]$. In some instances altered ERK activity could interfere with neuroglia wrapping of neuritis to form the myelin sheath. Newbern et al. recently reported that ablation of ERK1/2 in Schwann cell precursors resulted in hypomyelination of axons [72].

\section{Conclusions}

A large number of genetic mutations and $\mathrm{CNVs}$ have been linked to ASD. The implicated genes span a variety of functions and pathways [25,35]. Despite this diversity, defects in neuronal plasticity and dendrite morphology are commonly associated with this disease. In this report, we utilized shRNA knockdown of eight ASD-associated genes to examine downstream transcriptional alterations and to look for pathway-level commonalities. An underlying assumption is that dysregulation of these genes in primary mouse cortical neurons produce transcriptional alterations robust enough to be detected in lysates of these mixed cultures. As it is difficult in such an experiment to identify a single causal gene, analyzing changes at the pathway level mitigates the reliance on just one or two genes. Pathway analysis by two different approaches both identified alterations in a number of conserved neuronal signaling pathways. Detailed examination of those pathways emphasized alterations to the cAMP and ERK signaling pathways. These pathways would be good starting points for further functional characterization of common downstream neuronal phenotypes following known-down of ASD-associated genes. For example, cAMP reporter assays and phosphoproteomic analysis of ERK pathway regulation would be informative in searching for common intervention points that might reverse the phenotypes caused by the ASD gene disruption. The prospect that multiple genes tied to a single disorder converge on a common set of pathways provides hope that therapeutics can be developed that will be efficacious in a patient population with a heterogeneous genetic background.

\section{Additional files}

Additional file 1: Figure S1. Western blot analysis of protein knockdown. Additional file 2: Table S1. Full gene expression data.

Additional file 3: Table S2. Comparison of individual gene expression changes between knockdown datasets. Genes that had fold-changes $>1.5$ versus control with a $P$-value $<0.5$ were compared between experiments for overlap. The number of genes found in both knockdown experiments for any combination is shown on the table.

Additional file 4: Table S3. Gene set enrichment analysis utilizing Ingenuity pathways.

Additional file 5: Table S4. A comparison of common causal reasoning engine (CRE) hypotheses from the nine experiments A total of 269 hypotheses were observed in at least three of the experiments and not in the blank. The notation $(+)$ indicates the hypothesis is predicted to be upregulated, and (-) predicted it to be downregulated. Names highlighted in orange are part of the molecular interaction network (Figure 4). An observed hypothesis (indicated by a red box) satisfies the following filters: correctness $P$-value $<0.05$, enrichment $P$-value $<0.05$, minimum number of correctly explained gene expression changes $\geq 3$, percent correctly explained gene expression changes $\geq 60 \%$, ranking score $<100$. 


\section{Abbreviations}

ASD: Autism spectrum disorder; BDNF: Brain-derived neurotrophic factor; CNV: Copy number variant; CRE: Causal reasoning engine; DIV: Days in vitro; ELISA: Enzyme-linked immunosorbent assay; ERBB3: Receptor tyrosine-protein kinase erbB-3; Erk: Extracellular signal-regulated kinase; FDR: False discovery rate; FMRP: Fragile X mental retardation; Gapdh: Glyceraldehyde 3-phosphate dehydrogenase; GFP: Green fluorescent protein; GSEA: Gene set enrichment analysis; GSS: Gene Sensor Suite; GWAS: Genome-wide association studies; MECP2: Methyl-CpG binding protein 2; MEF: Myocyte enhancer factor; MOI: Multiplicity of infection; NLGN: Neuroligin; PBS: Phosphate-buffered saline; PTEN: Phosphatase and tensin homolog; qPCR: quantitative polymerase chain reaction; RT: Reverse transcriptase; SHANK3: SH3 and multiple ankyrin repeat domains 3; shRNA: short-hairpin RNA; TRKA: Neurotrophic tyrosine kinase receptor type 1 .

\section{Competing interests}

All authors were employees of Pfizer Global Research and Development, which funded this study, at the time the experimental work was conducted.

\section{Authors' contributions}

EG carried out the knockdown experiments, including the qPCR analysis and the preparation of samples for transcriptomic analysis. TAL, MMG, and JEF conducted the bioinformatic analysis of the transcriptomic data. TAL, LWF, and DTS conceived of the original project and experimental design. MTP coordinated data analysis and the preparation of the manuscript. EG, TAL, MMG, JEF, and MTP contributed to drafting of the manuscript. All authors read and approved the final manuscript.

\section{Acknowledgements}

We would like to thank Daniel Smith and Michael Ehlers for their helpful thoughts and comments and Ahmed Enayetallah and Diogo Camacho for their assistance with the causal reasoning engine.

\section{Author details}

'Neuroscience Research Unit, Pfizer Inc, Main Street, Cambridge, MA 02140, USA. ${ }^{2}$ Investigative Toxicology, Pfizer, Inc, Eastern Point Road, Groton, CT 06340, USA. ${ }^{3}$ Compound Safety Prediction, Pfizer, Inc, Eastern Point Road, Groton, CT 06340, USA. ${ }^{4}$ Rare Disease Research Unit, Pfizer, Inc, Cambridge Park Drive, Cambridge, MA 02140, USA. ${ }^{5}$ Current Address: LW Fitzgerald Consulting, LLC, 35 Plum Hill Rd., East Lyme, CT 06333, USA. ${ }^{6}$ Current Address: Critical Path Institute, East River Road, Tucson, AZ 85718, USA.

Received: 6 May 2013 Accepted: 9 October 2013

Published: 15 November 2013

\section{References}

1. CfDCa P: Prevalence of autism spectrum disorders - autism and developmental disabilities monitoring network, United States, 2006. MMWR Surveill Summ 2009, 58:1-20.

2. Rice CE, Baio J, Van Naarden Braun K, Doernberg N, Meaney FJ, Kirby RS: A public health collaboration for the surveillance of autism spectrum disorders. Paediatr Perinat Epidemiol 2007, 21:179-190.

3. Tchaconas A, Adesman A: Autism spectrum disorders: a pediatric overview and update. Curr Opin Pediatr 2013, 25:130-144.

4. Folstein SE, Rosen-Sheidley B: Genetics of autism: complex aetiology for a heterogeneous disorder. Nat Rev Genet 2001, 2:943-955.

5. Sanders SJ, Murtha MT, Gupta AR, Murdoch JD, Raubeson MJ, Willsey AJ, Ercan-Sencicek AG, DiLullo NM, Parikshak NN, Stein JL, Walker MF, Ober GT, Teran NA, Song Y, El-Fishawy P, Murtha RC, Choi M, Overton JD, Bjornson RD, Carriero NJ, Meyer KA, Bilguvar K, Mane SM, Sestan N, Lifton RP, Günel M, Roeder K, Geschwind DH, Devlin B, State MW: De novo mutations revealed by whole-exome sequencing are strongly associated with autism. Nature 2012, 485:237-241

6. Jiang $Y H$, Yuen RK, Jin X, Wang M, Chen N, Wu X, Ju J, Mei J, Shi Y, He M, Wang G, Liang J, Wang Z, Cao D, Carter MT, Chrysler C, Drmic IE, Howe JL, Lau L, Marshall CR, Merico D, Nalpathamkalam T, Thiruvahindrapuram B, Thompson A, Uddin M, Walker S, Luo J, Anagnostou E, Zwaigenbaum L, Ring RH, Wang J, Lajonchere C, Wang J, Shih A, Szatmari P, Yang H, Dawson G, Li Y, Scherer SW: Detection of clinically relevant genetic variants in autism spectrum disorder by whole-genome sequencing. Am J Hum Genet 2013, 93:249-263.
7. Buxbaum JD, Daly MJ, Devlin B, Lehner T, Roeder K, State MW: The autism sequencing consortium: large-scale, high-throughput sequencing in autism spectrum disorders. Neuron 2012, 76:1052-1056.

8. Coe BP, Girirajan S, Eichler EE: The genetic variability and commonality of neurodevelopmental disease. Am J Med Genet C: Semin Med Genet 2012, 160C:118-129.

9. Gillis RF, Rouleau GA: The ongoing dissection of the genetic architecture of autistic spectrum disorder. Mol Autism 2011, 2:12.

10. Smith DG, Ehlers MD: Mining and modeling human genetics for autism therapeutics. Curr Opin Neurobiol 2012, 22:902-910.

11. Arking DE, Cutler DJ, Brune CW, Teslovich TM, West K, lkeda M, Rea A, Guy M, Lin S, Cook EH, Chakravarti A: A common genetic variant in the neurexin superfamily member CNTNAP2 increases familial risk of autism. Am J Hum Genet 2008, 82:160-164.

12. Marshall CR, Noor A, Vincent JB, Lionel AC, Feuk L, Skaug J, Shago M, Moessner R, Pinto D, Ren $Y$, Thiruvahindrapduram B, Fiebig A, Schreiber S, Friedman J, Ketelaars CE, Vos YJ, Ficicioglu C, Kirkpatrick S, Nicolson R, Sloman L, Summers A, Gibbons CA, Teebi A, Chitayat D, Weksberg R, Thompson A, Vardy C, Crosbie V, Luscombe S, Baatjes R, Zwaigenbaum L, Roberts W, Fernandez B, Szatmari P, Scherer SW: Structural variation of chromosomes in autism spectrum disorder. Am J Hum Genet 2008, 82:477-488.

13. Tamada K, Tomonaga S, Hatanaka F, Nakai N, Takao K, Miyakawa T, Nakatani J, Takumi T: Decreased exploratory activity in a mouse model of $15 q$ duplication syndrome; implications for disturbance of serotonin signaling. PLoS One 2010, 5:e15126.

14. Weiss LA, Arking DE, Daly MJ, Chakravarti A: A genome-wide linkage and association scan reveals novel loci for autism. Nature 2009, 461:802-808

15. Zafeiriou DI, Ververi A, Vargiami E: Childhood autism and associated comorbidities. Brain Dev 2007, 29:257-272.

16. Chen WG, Chang Q, Lin Y, Meissner A, West AE, Griffith EC, Jaenisch R, Greenberg ME: Derepression of BDNF transcription involves calcium-dependent phosphorylation of MeCP2. Science 2003, 302:885-889.

17. Martinowich $K$, Hattori D, Wu H, Fouse S, He F, Hu Y, Fan G, Sun YE: DNA methylation-related chromatin remodeling in activity-dependent BDNF gene regulation. Science 2003, 302:890-893.

18. Banerjee-Basu S, Packer A: SFARI Gene: an evolving database for the autism research community. Dis Model Mech 2010, 3:133-135.

19. Bill BR, Geschwind DH: Genetic advances in autism: heterogeneity and convergence on shared pathways. Curr Opin Genet Dev 2009, 19:271-278.

20. Sakai Y, Shaw CA, Dawson BC, Dugas DV, Al-Mohtaseb Z, Hill DE, Zoghbi HY: Protein interactome reveals converging molecular pathways among autism disorders. Sci Transl Med 2011, 3:86.

21. Neale BM, Kou Y, Liu L, Ma'ayan A, Samocha KE, Sabo A, Lin CF, Stevens C, Wang LS, Makarov V, Polak P, Yoon S, Maguire J, Crawford EL, Campbell NG, Geller ET, Valladares O, Schafer C, Liu H, Zhao T, Cai G, Lihm J, Dannenfelser R, Jabado O, Peralta Z, Nagaswamy U, Muzny D, Reid JG, Newsham I, Wu Y, Lewis L, Han Y, Voight BF, Lim E, Rossin E, Kirby A, Flannick J, Fromer M, Shakir K, Fennell T, Garimella K, Banks E, Poplin R, Gabriel S, DePristo M, Wimbish JR, Boone BE, Levy SE, Betancur C, Sunyaev S, Boerwinkle E, Buxbaum JD, Cook EH $\mathrm{Jr}$, Devlin B, Gibbs RA, Roeder K, Schellenberg GD, Sutcliffe JS, Daly MJ: Patterns and rates of exonic de novo mutations in autism spectrum disorders. Nature 2012, 485:242-245.

22. O'Roak BJ, Vives L, Girirajan S, Karakoc E, Krumm N, Coe BP, Levy R, Ko A, Lee C, Smith JD, Turner EH, Stanaway IB, Vernot B, Malig M, Baker C, Reilly B, Akey JM, Borenstein E, Rieder MJ, Nickerson DA, Bernier R, Shendure J, Eichler EE: Sporadic autism exomes reveal a highly interconnected protein network of de novo mutations. Nature 2012, 485:246-250.

23. Bourgeron T: A synaptic trek to autism. Curr Opin Neurobiol 2009, 19:231-234.

24. Pardo CA, Eberhart CG: The neurobiology of autism. Brain Pathol 2007, 17:434-447

25. Huquet $\mathrm{G}, \mathrm{Ey} \mathrm{E}$, Bourgeron $\mathrm{T}$ : The genetic landscapes of autism spectrum disorders. Annu Rev Genomics Hum Genet 2013, 14:191-213.

26. Butler MG, Dasouki MJ, Zhou XP, Talebizadeh Z, Brown M, Takahashi TN, Miles JH, Wang CH, Stratton R, Pilarski R, Eng C: Subset of individuals with autism spectrum disorders and extreme macrocephaly associated with germline PTEN tumour suppressor gene mutations. J Med Genet 2005, 42:318-321.

27. Fraser MM, Bayazitov IT, Zakharenko SS, Baker SJ: Phosphatase and tensin homolog, deleted on chromosome 10 deficiency in brain causes defects in synaptic structure, transmission and plasticity, and myelination abnormalities. Neuroscience 2008, 151:476-488. 
28. Luikart BW, Schnell E, Washburn EK, Bensen AL, Tovar KR, Westbrook GL: Pten knockdown in vivo increases excitatory drive onto dentate granule cells. J Neurosci 2011, 31:4345-4354

29. Durand CM, Betancur C, Boeckers TM, Bockmann J, Chaste P, Fauchereau F, Nygren G, Rastam M, Gillberg IC, Anckarsater H, Sponheim E, Goubran-Botros H, Delorme R, Chabane N, Mouren-Simeoni MC, de Mas P, Bieth E, Rogé B, Héron D, Burglen L, Gillberg C, Leboyer M, Bourgeron T: Mutations in the gene encoding the synaptic scaffolding protein SHANK3 are associated with autism spectrum disorders. Nat Genet 2007, 39:25-27.

30. Glessner JT, Wang K, Cai G, Korvatska O, Kim CE, Wood S, Zhang H, Estes A, Brune CW, Bradfield JP, Imielinski M, Frackelton EC, Reichert J, Crawford EL, Munson J, Sleiman PM, Chiavacci R, Annaiah K, Thomas K, Hou C, Glaberson W, Flory J, Otieno F, Garris M, Soorya L, Klei L, Piven J, Meyer KJ, Anagnostou E, Sakurai T, Game RM, Rudd DS, Zurawiecki D, McDougle CJ, Davis LK, Miller J, Posey DJ, Michaels S, Kolevzon A, Silverman JM, Bernier R, Levy SE, Schultz RT, Dawson G, Owley T, McMahon WM, Wassink TH, Sweeney JA, Nurnberger JI, Coon H, Sutcliffe JS, Minshew NJ, Grant SF, Bucan M, Cook EH, Buxbaum JD, Devlin B, Schellenberg GD, Hakonarson H: Autism genome-wide copy number variation reveals ubiquitin and neuronal genes. Nature 2009, 459:569-573.

31. Jamain S, Quach H, Betancur C, Rastam M, Colineaux C, Gillberg IC, Soderstrom H, Giros B, Leboyer M, Gillberg C, Bourgeron T: Mutations of the X-linked genes encoding neuroligins NLGN3 and NLGN4 are associated with autism. Nat Genet 2003, 34:27-29.

32. Flavell SW, Kim TK, Gray JM, Harmin DA, Hemberg M, Hong EJ, Markenscoff-Papadimitriou E, Bear DM, Greenberg ME: Genome-wide analysis of MEF2 transcriptional program reveals synaptic target genes and neuronal activity-dependent polyadenylation site selection. Neuron 2008, 60:1022-1038.

33. Flavell SW, Cowan CW, Kim TK, Greer PL, Lin Y, Paradis S, Griffith EC, Hu LS, Chen C, Greenberg ME: Activity-dependent regulation of MEF2 transcription factors suppresses excitatory synapse number. Science 2006, 311:1008-1012.

34. Katayama T, Hattori T, Yamada K, Matsuzaki S, Tohyama M: Role of the PACAP-PAC1-DISC1 and PACAP-PAC1-stathmin1 systems in schizophrenia and bipolar disorder: novel treatment mechanisms? Pharmacogenomics 2009, 10:1967-1978.

35. Toro R, Konyukh M, Delorme R, Leblond C, Chaste P, Fauchereau F, Coleman M, Leboyer M, Gillberg C, Bourgeron T: Key role for gene dosage and synaptic homeostasis in autism spectrum disorders. Trends Genet 2010, 26:363-372.

36. Zhang SJ, Steijaert MN, Lau D, Schutz G, Delucinge-Vivier C, Descombes P, Bading $\mathrm{H}$ : Decoding NMDA receptor signaling: identification of genomic programs specifying neuronal survival and death. Neuron 2007, 53:549-562.

37. Hagberg B, Aicardi J, Dias K, Ramos O: A progressive syndrome of autism, dementia, ataxia, and loss of purposeful hand use in girls: Rett's syndrome: report of 35 cases. Ann Neurol 1983, 14:471-479.

38. Hatton DD, Sideris J, Skinner M, Mankowski J, Bailey DB Jr, Roberts J, Mirrett P: Autistic behavior in children with fragile $\mathrm{X}$ syndrome: prevalence, stability, and the impact of FMRP. Am J Med Genet A 2006, 140A:1804-1813.

39. Conti S, Condo M, Posar A, Mari F, Resta N, Renieri A, Neri I, Patrizi A, Parmeggiani A: Phosphatase and tensin homolog (PTEN) gene mutations and autism: literature review and a case report of a patient with cowden syndrome, autistic disorder and epilepsy. J Child Neurol 2011, 29:29.

40. Irizarry RA, Hobbs B, Collin F, Beazer-Barclay YD, Antonellis KJ, Scherf U, Speed TP: Exploration, normalization, and summaries of high density oligonucleotide array probe level data. Biostatistics 2003, 4:249-264.

41. Smyth GK: Linear models and empirical bayes methods for assessing differential expression in microarray experiments. Stat Appl Genet Mol Biol 2004, 3

42. Benjamini $Y$, Hochberg Y: Controlling the false discovery rate: a practical and powerful approach to multiple testing. J Roy Statistical Soc 1995, 57:289-300

43. Kupershmidt I, Su QJ, Grewal A, Sundaresh S, Halperin I, Flynn J, Shekar M, Wang H, Park J, Cui W, Wall GD, Wisotzkey R, Alag S, Akhtari S, Ronaghi M: Ontology-based meta-analysis of global collections of high-throughput public data. PLoS One 2010, 5.

44. Liberzon A, Subramanian A, Pinchback R, Thorvaldsdottir H, Tamayo $P$, Mesirov JP: Molecular signatures database (MSigDB) 3.0. Bioinformatics 2011, 27:1739-1740.

45. Gosink M, Khuri S, Valdes C, Jiang Z, Tsinoremas NF: GenSensor suite: a Web-based tool for the analysis of gene and protein interactions, pathways, and regulation. Adv Bioinformatics 2011, 2011:271563.
46. Store J: A direct approach to false discovery rate. J R Stat Soc Ser B 2002, 64:479-498.

47. Chindelevitch L, Ziemek D, Enayetallah A, Randhawa R, Sidders B, Brockel C, Huang E: Causal Reasoning on Biological Networks: Interpreting Transcriptional Changes. In Bioinformatics 2012, 28:1114-21.

48. Enayetallah AE, Ziemek D, Leininger MT, Randhawa R, Yang J, Manion TB, Mather DE, Zavadoski WJ, Kuhn M, Treadway JL, des Etages SA, Gibbs EM, Greene N, Steppan CM: Modeling the mechanism of action of a DGAT1 inhibitor using a causal reasoning platform. PLoS One 2011, 6:e27009.

49. Shannon P, Markiel A, Ozier O, Baliga NS, Wang JT, Ramage D, Amin N, Schwikowski B, Ideker T: Cytoscape: a software environment for integrated models of biomolecular interaction networks. Genome Res 2003, 13:2498-2504.

50. Chaignat E, Yahya-Graison EA, Henrichsen CN, Chrast J, Schutz F, Pradervand S, Reymond A: Copy number variation modifies expression time courses. Genome Res 2011, 21:106-113.

51. Somel M, Franz H, Yan Z, Lorenc A, Guo S, Giger T, Kelso J, Nickel B, Dannemann M, Bahn S, Webster MJ, Weickert CS, Lachmann M, Pääbo S, Khaitovich P: Transcriptional neoteny in the human brain. Proc Natl Acad Sci USA 2009, 106:5743-5748.

52. Valor LM, Charlesworth P, Humphreys L, Anderson CN, Grant SG: Network activity-independent coordinated gene expression program for synapse assembly. Proc Natl Acad Sci USA 2007, 104:4658-4663.

53. Hollander MC, Blumenthal GM, Dennis PA: PTEN loss in the continuum of common cancers, rare syndromes and mouse models. Nat Rev Cancer 2011, 11:289-301.

54. Ishihara H, Sasaoka T, Kagawa S, Murakami S, Fukui K, Kawagishi Y, Yamazaki K, Sato A, Iwata M, Urakaze M, Ishiki M, Wada T, Yaguchi S, Tsuneki H, Kimura I, Kobayashi M: Association of the polymorphisms in the 5'-untranslated region of PTEN gene with type 2 diabetes in a Japanese population. FEBS Lett 2003, 554:450-454

55. Ehlert EM, Eggers R, Niclou SP, Verhaagen J: Cellular toxicity following application of adeno-associated viral vector-mediated RNA interference in the nervous system. BMC Neurosci 2010, 11:20.

56. Persengiev SP, Zhu X, Green MR: Nonspecific, concentration-dependent stimulation and repression of mammalian gene expression by small interfering RNAs (siRNAs). Rna 2004, 10:12-18.

57. Davis E, Fennoy I, Laraque D, Kanem N, Brown G, Mitchell J: Autism and developmental abnormalities in children with perinatal cocaine exposure. J Natl Med Assoc 1992, 84:315-319.

58. Marin MT, Berkow A, Golden SA, Koya E, Planeta CS, Hope BT: Context-specific modulation of cocaine-induced locomotor sensitization and ERK and CREB phosphorylation in the rat nucleus accumbens. Eur J Neurosci 2009, 30:1931-1940.

59. Tropea TF, Kosofsky BE, Rajadhyaksha AM: Enhanced CREB and DARPP-32 phosphorylation in the nucleus accumbens and CREB, ERK, and GluR1 phosphorylation in the dorsal hippocampus is associated with cocaine-conditioned place preference behavior. J Neurochem 2008, 106:1780-1790.

60. Hoffmann HM, Nadal R, Vignes M, Ortiz J: Chronic cocaine selfadministration modulates ERK1/2 and CREB responses to dopamine receptor agonists in striatal slices. Addict Biol 2011, 17:565-575.

61. Dufour-Rainfray D, Vourc'h P, Tourlet S, Guilloteau D, Chalon S, Andres CR: Fetal exposure to teratogens: evidence of genes involved in autism. Neurosci Biobehav Rev 2011, 35:1254-1265.

62. Hao Y, Creson T, Zhang L, Li P, Du F, Yuan P, Gould TD, Manji HK, Chen G: Mood stabilizer valproate promotes ERK pathway-dependent cortical neuronal growth and neurogenesis. J Neurosci 2004, 24:6590-6599.

63. Zou H, Yu Y, Sheikh AM, Malik M, Yang K, Wen G, Chadman KK, Brown WT Li X: Association of upregulated Ras/Raf/ERK1/2 signaling with autism. Genes Brain Behav 2011, 10:615-624.

64. Yang K, Sheikh AM, Malik M, Wen G, Zou H, Brown WT, Li X: Upregulation of Ras/Raf/ERK1/2 signaling and ERK5 in the brain of autistic subjects. Genes Brain Behav 2011, 10:834-43.

65. Boulton TG, Gregory JS, Cobb MH: Purification and properties of extracellular signal-regulated kinase 1 , an insulin-stimulated microtubule-associated protein 2 kinase. Biochemistry 1991, 30:278-286.

66. Papandrikopoulou A, Doll T, Tucker RP, Garner CC, Matus A: Embryonic MAP2 lacks the cross-linking sidearm sequences and dendritic targeting signal of adult MAP2. Nature 1989, 340:650-652. 
67. Richter-Landsberg C, Jastorff B: In vitro phosphorylation of microtubule-associated protein 2: differential effects of cyclic AMP analogues. J Neurochem 1985, 45:1218-1222.

68. Zhou FQ, Snider WD: Intracellular control of developmental and regenerative axon growth. Philos Trans R Soc Lond B Biol Sci 2006, 361:1575-1592.

69. Vaillant AR, Zanassi P, Walsh GS, Aumont A, Alonso A, Miller FD: Signaling mechanisms underlying reversible, activity-dependent dendrite formation. Neuron 2002, 34:985-998.

70. Hoogenraad CC, Akhmanova A: Dendritic spine plasticity: new regulatory roles of dynamic microtubules. Neuroscientist 2010, 16:650-661.

71. Mazzucchelli C, Vantaggiato C, Ciamei A, Fasano S, Pakhotin P, Krezel W, Welzl H, Wolfer DP, Pages G, Valverde O, Marowsky A, Porrazzo A, Orban PC, Maldonado R, Ehrengruber MU, Cestari V, Lipp HP, Chapman PF, Pouysségur J, Brambilla R: Knockout of ERK1 MAP kinase enhances synaptic plasticity in the striatum and facilitates striatal-mediated learning and memory. Neuron 2002, 34:807-820.

72. Newbern JM, Li X, Shoemaker SE, Zhou J, Zhong J, Wu Y, Bonder D, Hollenback S, Coppola G, Geschwind DH, Landreth GE, Snider WD: Specific functions for ERK/MAPK signaling during PNS development. Neuron 2011, 69:91-105.

doi:10.1186/2040-2392-4-45

Cite this article as: Lanz et al:: Transcriptomic analysis of genetically defined autism candidate genes reveals common mechanisms of action. Molecular Autism 2013 4:45.

\section{Submit your next manuscript to BioMed Central and take full advantage of:}

- Convenient online submission

- Thorough peer review

- No space constraints or color figure charges

- Immediate publication on acceptance

- Inclusion in PubMed, CAS, Scopus and Google Scholar

- Research which is freely available for redistribution 